\title{
X-linked spinocerebellar ataxia type 4
}

INSERM

\section{Source}

INSERM. (1999). Orphanet: an online rare disease and orphan drug data base. $\underline{X \text {-linked }}$ spinocerebellar ataxia type 4. ORPHA:85292

Spinocerebellar ataxia, $\mathrm{X}$-linked, type 4 is characterised by ataxia, pyramidal tract signs and adult-onset dementia. It has been described in three generations of one large family. The disease manifests during early childhood with delayed walking and tremor. The pyramidal signs appear progressively and by adulthood memory problems and dementia gradually become apparent. Transmission is X-linked but the causative gene has not yet been identified. The disease is usually fatal during the sixth decade of life. 